\title{
Article \\ Assessment of the Working Performance of an Innovative Prototype to Harvest Hemp Seed in Two Different Conditions of Terrain Slope
}

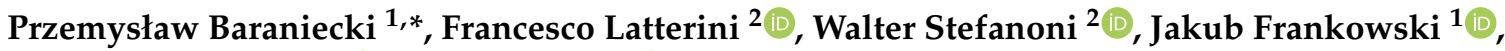 \\ Katarzyna Wielgusz ${ }^{1}\left(\mathbb{D}\right.$ and Luigi Pari ${ }^{2}$ (D)
}

1 Instytut Włókien Naturalnych i Roślin Zielarskich Państwowy Instytut Badawczyul, Wojska Polskiego 71 b, 60-630 Poznań, Poland; jakub.frankowski@iwnirz.pl (J.F.); katarzyna.wielgusz@iwnirz.pl (K.W.)

2 Centro di Ricerca Ingegneria e Trasformazioni Agroalimentari, Consiglio per la Ricerca in Agricoltura e l'Analisi dell'Economia Agraria, Via della Pascolare 16, 00015 Monterotondo, Italy; francesco.latterini@crea.gov.it (F.L.); walter.stefanoni@crea.gov.it (W.S.); luigi.pari@crea.gov.it (L.P.)

* Correspondence: przemyslaw.baraniecki@iwnirz.pl; Tel.: +48-61-84-55-821

check for

updates

Citation: Baraniecki, P.; Latterini, F. Stefanoni, W.; Frankowski, J.;

Wielgusz, K.; Pari, L. Assessment of the Working Performance of an Innovative Prototype to Harvest Hemp Seed in Two Different Conditions of Terrain Slope. Agronomy 2022, 12, 185. https:// doi.org/10.3390/agronomy12010185

Academic Editors: Federica Zanetti, Christina Eynck and Xiangjun Zou

Received: 22 November 2021

Accepted: 11 January 2022

Published: 12 January 2022

Publisher's Note: MDPI stays neutral with regard to jurisdictional claims in published maps and institutional affiliations.

Copyright: (C) 2022 by the authors. Licensee MDPI, Basel, Switzerland. This article is an open access article distributed under the terms and conditions of the Creative Commons Attribution (CC BY) license (https:// creativecommons.org/licenses/by/ $4.0 /)$

\begin{abstract}
After many decades when its cultivation was prohibited, hemp is regaining its position as one of the most versatile cultivated crops. Multiplication of monoecious hemp varieties requires manual male plants rouging to keep a high share of monoecious plants in the population. It forces relatively small multiplication fields usually oscillating around $5 \mathrm{ha}$, where the use of big harvesting machines is not economically feasible. The B- 800 mower prototype for hemp panicles proved to be a good alternative to harvest seeds of tall fibrous hemp. The test results of the mower analyzed in this study show that although seed loss on a moderate slope $(0.37 \%)$ was significantly higher than on a flat slope $(0.13 \%)$, it was still much lower than in the case of harvesting hemp seed with a combined harvester. Moreover, the field efficiency of $93 \%$ is very satisfactory as it is reported for much bigger machines. Finally, the harvesting costs proved to be much lower than most of the machines used for harvesting hemp seed.
\end{abstract}

Keywords: hemp seed harvest; seed loss; operative time; cost assessment; effective field capacity

\section{Introduction}

Hemp (Cannabis sativa L.) is a multipurpose crop increasing its cultivation area in recent years in Europe. In 2015-2019 the cultivation area of industrial hemp increased from 20,000 ha to 34,000 ha (70\% increase) in the EU alone [1].

Hemp is a source of raw material for a wide variety of uses and final products from animal bedding, through composites, cosmetics to food, food supplements products, pharmaceuticals, and sowing seeds [2-4]. This variety of uses means that hemp must be harvested in different ways, at different stages of plant development which in turn poses specific challenges in the harvesting process. These challenges are magnified by the fact that often the harvesting process is connected with a substantial height of plants that contain very strong and highly lignified fiber and huge total fresh biomass to handle by the harvesting machines, reaching $65 \mathrm{t} / \mathrm{ha}$ [5]. One should also not forget that the total hemp cultivation area, although is gradually increasing over recent years, is still relatively very small compared to most of the commodity crops in Europe, such as small grains, maize, rapeseed potatoes, or sugar beet [6]. All these factors influence the process of developing harvesting machines making it not an easy task. As the result, there are a number of prototypes, sometimes developed by passionate and a few commercialized harvesters that are either especially, constructionally developed to harvest particular parts of hemp or harvesters developed to handle other bulk crops and adopted to harvest hemp $[7,8]$. All these machines were developed mostly to harvest grain, inflorescence, or straw for different purposes. 
A separate issue is the harvest of hemp for certified sowing seed, especially in the case of monoecious fiber varieties. In addition to the challenges true to any other uses of hemp mentioned above, very specific ones appear. When harvesting hemp for sowing seed, the plant is fully matured which means the fiber amount and its lignification is at their highest degree. This makes the handling of the biomass even more difficult. The other issue is of economic character. In monoecious hemp varieties, it is a must to remove male plants that voluntarily appear in the sowing seed multiplication field to meet officially accepted male plant percentage thresholds. Since it is male plants that carry mainly the trait of dioeciousness, rouging male plants before pollination prevents increasing the number of male plants in the population in the following generations. This work can be performed only manually, therefore, the area of sowing seed plantation usually should not be larger than 5 ha or so. This often makes it unfeasible to use big harvesting machines that are designed to work on hundreds of hectares. Hence, there was a need to develop a harvesting machine that is economically feasible on small sowing seed-producing plantations.

Furthermore, when dealing with industrial crops, it is not possible to not mention the fundamental issue of growing such species on marginal lands, in order to avoid competition with food crops $[9,10]$. Therefore, machineries working on hemp have to be able to work also in marginal conditions, for instance on a moderately steep slope-a proper slope is one of the major factors defining marginal lands in Europe [11].

Considering what has previously been reported, an innovative prototype to harvest hemp for certified seed sowing has been developed, with the aim of obtaining machinery able to tackle all the mentioned above issues that arise in this particular harvesting operation.

Notwithstanding, mechanical harvesting represents one of the main bottlenecks for the development of an effective supply chain for several industrial crops [12]; studies dealing with the evaluation of the working performance of harvesters for seed hemp are scarce in current literature. Moreover, no scientific evaluation of the performance of machinery to harvest hemp for certified sowing seed has been reported in the literature.

Taking the above mentioned into account, the objective of this work was to properly perform the first scientific evaluation of an innovative prototype to harvest hemp for certified sowing seed, evaluating its performance in terms of seed loss, work productivity, and harvesting costs in two different conditions of a slope, i.e., flat slope (up to $5 \%$ ) and moderate slope (5-15\%); evaluating therefore also the suitability of such prototype to working in a situation of slight marginality.

\section{Materials and Methods}

\subsection{Study Area}

Tests of the mower were conducted on the field located in village Podhorce, Poland, woj. Lubelskie, Powiat Tomaszowski, Gmina Tomaszów Lubelski, (WGS 84 coordinates: $50.473700^{\circ} \mathrm{N} ; 23.526535^{\circ}$ E, $257 \mathrm{~m}$ a.s.l., Figure 1a), in September 2020. The field for testing was made available to the courtesy of a farmer with whom the Institute of Natural Fibres and Medicinal Plants had a contract for the reproduction of hemp sowing seed. The total area of the field was 3.55 ha. As it is possible to notice in Figure 1b,c, in the field there are two areas with a flat slope (north and south of the field) and a central zone with a steeper slope. Details of the two different zones characterized by different slope conditions are given in Table 1.

The information on the nutritional values of the soil and texture of the soil in this particular field was not available. According to available soil information from the farmer, the plantation was established on the brown soils developed from loess on a limestone substrate. The previous crop was spring barley.

Tillage treatments were typical ones as recommended for the hemp grown for certified sowing seed and covered deep $(25 \mathrm{~cm})$ winter plough in the autumn and harrowing and ragging in spring before sowing. 



Figure 1. (a) Vision of the experimental field on satellite image. (b) Slope map of the experimental field where it is possible to identify the zones with different slope. (c) Three-dimensional (3D) model of the experimental field.

Table 1. Characteristics of the two different zones of the experimental field.

\begin{tabular}{|c|c|c|}
\hline Parameter & Flat Slope (FS) & Moderate Slope (MS) \\
\hline Prevalent slope (\%) & 3.50 & 9.50 \\
\hline Surface (ha) & 2.30 & 1.25 \\
\hline Total surface (ha) & & \\
\hline
\end{tabular}

Two types of mineral fertilizers were applied before planting: a multicomponent Polifoska 6 containing $6 \%$ of nitrogen, $20 \%$ of phosphorus, $30 \%$ of potassium, and $7 \%$ of sulphur at $300 \mathrm{~kg} / \mathrm{ha}$ and Saletrzak Standard containing $27 \%$ of nitrogen, $2 \%$ of $\mathrm{CaO}$, and $4 \%$ of $\mathrm{MgO}$ at $150 \mathrm{~kg} / \mathrm{ha}$. Both fertilizers were applied the same day-18th April.

Sowing took place on 9 May by the pneumatic drill at $10 \mathrm{~kg} / \mathrm{ha}$ in rows spaced at $45 \mathrm{~cm}$. Only monocotyledon weeds can be controlled effectively in hemp as no reliable chemical is registered for dicodyledon weeds in Poland. In this particular field, Fusilade Forte 150EC at $0.6 \mathrm{dm}^{3} /$ ha was applied on 30th May. Manual rouging of appearing male plants was conducted on the field from the beginning of bloom for the period of approximately 3 weeks. Seed harvesting took place on 21 September 2020 using a B-800 hemp mower. Plants were harvested at the full biological maturity of plants when seeds were mature in the middle of the panicle and the first seed began shedding.

The available rainfall data come partly from the weather station of the Instytut Meteorologii i Gospodarki Wodnej-Państwowy Instytut Badawczy located about 9 km S-W from the field, in Tomaszów Lubelski. Another part of the data came from the weatherspark portal (https://weatherspark.com). Total rainfall from April to September (sowing to harvest) was $399.11 \mathrm{~mm}$ but was very unevenly distributed across the months. Particularly, April and May were very dry as only 5.4 and $3.8 \mathrm{~mm}$ was recorded in these two months, 
respectively. Even though these values are very small against the average values (approximately $33.5 \mathrm{~mm}$ and $50.5 \mathrm{~mm}$, respectively), the germination was satisfactory. The rainfall in the following months (June-September) was above normal and plants were developing properly. The meteorological data are presented in Table 2.

Table 2. Monthly rainfall sums and monthly average temperatures in the vegetation period of the study (April-September).

\begin{tabular}{ccc}
\hline Month & Monthly Rainfall Sum [mm] & Monthly Average Temp. $\left[{ }^{\circ} \mathbf{C}\right]$ \\
\hline March & 34.8 & 3.97 \\
April & 5.4 & 8.02 \\
May & 3.8 & 10.93 \\
June & 131.7 & 18.30 \\
July & 97.5 & 18.51 \\
August & 74.6 & 19.27 \\
September & 86.1 & 14.39 \\
Rainfall sum & 399.11 & - \\
\hline
\end{tabular}

The lantation-where hemp mower was tested-was planted with a certified basic seed of monoecius Białobrzeskie, a typical fiber variety developed at the Institute of Natural Fibres and Medicinal Plants-State Research Institute.

\subsection{Description of the Prototype}

The B-800 mower for hemp panicles (Figure 2) developed to harvest sowing seed plantations is the answer to the technological gap in hemp harvesting machines dedicated to harvesting seed in small plantations. The machine is developed in cooperation between the Institute of Natural Fibres and Medicinal Plants, National Research Institute and Company FUGOR Sp. z o.o. from Krotoszyn, Poland, based on the idea and experience of the Institute. The intellectual property of the Institute is secured in the form of design rights.



Figure 2. Vision of the prototype.

The mower is composed of two main sections: the cutting section with belt conveyors mounted on the front-end loader and a hydraulic power pack with an oil container mounted on a three-point hitch of a tractor. The cutting unit is a movable knife bar which is a system of serrated cutting knives with alternately configured cutting planes and double fingers. The cutting width is $2.5 \mathrm{~m}$. Above the cutting unit there is a powered reel that can be raised or lowered. The reel setting is controlled from the tractor cabin using a remote control. The power supply of all mower elements is hydraulic. Mounting the mower on a front-end loader allows for a cutting range from 0.6 to $4.0 \mathrm{~m}$ from the ground.

The cut panicles are moved on the belt conveyors and are then loaded on the trailer moving parallel to the mower. 
The threshing of panicles is carried out separately as is the mowing of the tall stubble.

The minimum power requirement of a tractor for the mower is $102.9 \mathrm{~kW}$. For the tests, the mower was attached to the John Deere 6830 tractor with $104.4 \mathrm{~kW}$ power.

\subsection{Pre-Harvest Test}

Three blocks were designated in the field to take pre-harvest biomass samples and conduct mower performance tests. Each block was $100 \mathrm{~m}$ long and $7.5 \mathrm{~m}$ wide (3 times the working width of the mower). Two blocks were located in the flat slope zone and one in the steep slope zone.

Prior to the harvest the 15 sample plots (five in each block) of $1 \mathrm{~m}^{2}$ each were randomly selected to evaluate the total above-ground biomass, corresponding therefore in 10 sample plots in the flat zone and 5 in the steep one. The plants in each plot were manually harvested using a lopper. Plants were cut right above the ground and taken to the shed for drying and the assessment of fresh and dry weight. The dried straw was weighted, then panicles were cut off and threshed manually. The obtained threshing material was packed in paper bags for cleaning and estimation of seed yield. Prior to that, ten randomly taken dry plants were measured (total straw length, technical straw length, and panicle length). The seeds were separated from the threshed material and cleaned in the Laboratory of the IWNiRZ PIB Research Station in Pętkowo using Paul Polikeit laboratory seed cleaner.

Additionally, another 15 (10 in flat slope and 5 in steep one) plots $1 \mathrm{~m}^{2}$ each were selected to measure the losses of seed during harvesting. In each of these plots, the number of seeds on the ground was counted just before and right after the harvest. Seeds were then dried and weighted for the calculation of seed loss for natural dehiscence (DSL) and seed loss related to harvesting operation (HSL), obtained values were expressed in both \% ww and $\mathrm{kg} / \mathrm{ha} \mathrm{DM}$.

\subsection{Work Productivity and Cost Analysis}

For the evaluation of working time and productivity, 9 sample plots were established within the experimental field (6 in flat zone and 3 in steep zone). Each sample plot corresponded to a surface of $250 \mathrm{~m}^{2}$. Working times were calculated according to the procedure reported in [13]. Specifically, the working times were divided into: operative time, maneuvers time, and delay time (avoidable + unavoidable). No accessory time was recorded in this specific field trial. Working times were used to calculate the following parameters to estimate the work productivity of the prototype:

- $\quad$ Theoretical field capacity (TFC, ha/h): Working speed x working width;

- $\quad$ Effective field capacity (EFC, ha/h): Harvested surface/overall working time;

- $\quad$ Material capacity (MC, ha/h): Harvested seeds/overall working time.

Concerning costs analysis, the purchase cost of tractors and of the trailer was provided by the farmer, while the cost of the prototype was estimated according to the cost of the mower on which it was developed, working performance of the harvesting system was obtained from the results of the field trials and used as input data. Standard coefficients for calculation were taken from the methodology proposed by [14]. The hourly cost of the harvesting system was calculated considering the market value of the agricultural machinery implied. The price of the machine was discounted to 2020, through the application of a lending rate of $8 \%$ as proposed by Magagnotti et al. (2021) in a similar study recently carried out in Poland [15]. Fuel consumption was assessed through the re-filling method in each sample plot. The fuel used was recorded and used for the calculation of fuel consumption. Lubricant consumption was evaluated according to the [16]. Values for the various parameters used for the economic evaluation are reported in Table 3. 
Table 3. Parameters and values applied for cost analysis.

\begin{tabular}{|c|c|c|c|c|c|}
\hline & & Tractor for Prototype & Prototype & Tractor for Trailer & Trailer \\
\hline Purchase cost & EUR & 78,000 & 26,200 & 26,000 & 7000 \\
\hline Service life & yr & 10 & 10 & 10 & 10 \\
\hline Service life & $\mathrm{h}$ & 14,000 & 2000 & 14,000 & 3000 \\
\hline Resale & $\%$ & $29.54 \%$ & $18.86 \%$ & $29.54 \%$ & $17.68 \%$ \\
\hline Resale & EUR & $23,039.96$ & 4942.13 & 7679.99 & 1237.89 \\
\hline Depreciation & EUR & $54,960.04$ & $21,257.87$ & $18,320.01$ & 5762.11 \\
\hline Annual usage & $\mathrm{h} / \mathrm{yr}$ & 300 & 300 & 300 & 300 \\
\hline Interest rate & $\%$ & 8 & 8 & 8 & 8 \\
\hline Ownership costs & EUR/y & 5496.00 & 2125.79 & 1832.00 & 576.21 \\
\hline Interests & $\mathrm{EUR} / \mathrm{y}$ & 4041.60 & 1245.69 & 1347.20 & 329.52 \\
\hline Machine shelter & $\mathrm{m}^{2}$ & 9.12 & 11.08 & 6.00 & 10.2 \\
\hline Value of the shelter & $\mathrm{EUR} / \mathrm{m}^{2}$ & 100 & 100 & 100 & 100 \\
\hline Value of the shelter & EUR/y & 18.24 & 22.15 & 12.00 & 20.4 \\
\hline Insurance & $\mathrm{EUR} / \mathrm{y}$ & 195.00 & 65.50 & 65.00 & 17.50 \\
\hline Repair factor & $\%$ & 80 & 80 & 80 & 80 \\
\hline Repair and maintenance & $\mathrm{EUR} / \mathrm{h}$ & 0.96 & 15.72 & 0.32 & 1.87 \\
\hline Fuel cost & EUR/1 & 1.09 & 1.09 & 1.09 & 1.09 \\
\hline Fuel consumption & $1 / \mathrm{h}$ & 34.21 & & 11.6 & \\
\hline Fuel consumption & EUR/h & 37.29 & & 12.64 & \\
\hline Lubricant cost & EUR/1 & 3.03 & & 3.03 & \\
\hline Lubricant consumption & $1 / \mathrm{h}$ & 0.28 & & 0.22 & \\
\hline Lubricant cost & $\mathrm{EUR} / \mathrm{h}$ & 0.84 & & 0.66 & \\
\hline Worker salary & $\mathrm{EUR} / \mathrm{h}$ & 16 & & 16 & \\
\hline
\end{tabular}

\subsection{Statistical Analysis}

ANOVA and Tukey LSD tests were performed through STATISTICA StatSoft version 7.0. to separate different means among treatments $(p \leq 0.05)$.

\section{Results and Discussion}

\subsection{Agronomic Features and Seed Loss Evaluation}

Results obtained from the pre-harvest test are given in Table 4. As it is possible to notice, plant height and also panicle length resulted significantly higher in FS while instead no statistically significant difference was found regarding plant density, seed yield, and biomass amount (both fresh and dry ones). Hemp is a multipurpose crop grown for a high number of uses. Each of such use requires specific agronomic regimes to produce a particular product most effectively. Comparing the agronomic features of the crop with previous field trials of hemp cultivation in similar climatic conditions it is possible to say that the seed yield obtained in the study was high. Calloway [17] reported that the Finola variety is capable of $2.0 \mathrm{Mg} /$ ha seed yields in good conditions. However, Finola is a seedproducing variety suitable for cultivation-especially in northern areas. Even higher seed yield was reported by Tsaliki et al. [2]. The $2.9 \mathrm{Mg} /$ ha seed yield of Bialobrzeskie variety, however, reported in this study was achieved in the Mediterranean, at five times higher sowing rate $(50 \mathrm{~kg} / \mathrm{ha})$, with irrigation and in field experiment conditions, while this study was conducted at full-size field plantation conducted in rain-fed regime in Poland climatic conditions. Other authors report much lower seed yield of Bialobrzeskie from slightly over $500 \mathrm{~kg} /$ ha to ca $450 \mathrm{~kg} / \mathrm{ha}$, under influence of increasing $\mathrm{N}$ fertilization (from 0 to $100 \mathrm{kgN} / \mathrm{ha}$ [18] and ca $750 \mathrm{~kg} / \mathrm{ha}$ (agronomic characteristics of some hemp genotypes., 1999) at seed density of 40-60 kg/ha and $\mathrm{N}$ dose of $90-120 \mathrm{~kg} / \mathrm{ha}$. The balance of nutrients supplied to the plant determines the quantity and quality of the crop. Due to the taproot system, hemp can also take up nutrients from the deeper layers of the soil. Hemp is a species that responds well to both organic (manure) and mineral fertilization [19-21]. 
Table 4. Agronomic features of the crop and seed loss evaluation. " $*$ " indicates statistically significant difference at $p<0.05$; “**" indicates statistically significant difference at $p<0.01$ and " "***" indicates statistically significant difference at $p<0.001$.

\begin{tabular}{|c|c|c|c|c|c|}
\hline \multirow[b]{2}{*}{ Parameter } & \multicolumn{2}{|c|}{ Flat Slope (FS) } & \multicolumn{2}{|c|}{ Moderate Slope (MS) } & \multirow[b]{2}{*}{ Significance Level } \\
\hline & Avg. & St.Dev. & Avg. & St.Dev. & \\
\hline Plant height $(\mathrm{cm})$ & 269.47 & 39.51 & 226.98 & 47.09 & $* * *$ \\
\hline Panicle length $(\mathrm{cm})$ & 55.25 & 25.71 & 41.46 & 22.30 & $* *$ \\
\hline Plant density $\left(\mathrm{N} / \mathrm{m}^{2}\right)$ & 198 & 35 & 196 & 26 & n.s. \\
\hline Seed yield (kg/ha) & 1540.99 & 439.85 & 1111.84 & 509.64 & n.s. \\
\hline Fresh biomass (Mg/ha) & 60.16 & 16.98 & 40.50 & 16.27 & n.s. \\
\hline Dry biomass (Mg/ha) & 17.47 & 7.26 & 10.10 & 4.43 & n.s. \\
\hline Dehiscence Seed Loss DSL (kg/ha DM) & 8.60 & 1.46 & 11.92 & 1.92 & $* *$ \\
\hline Harvesting seed LossHSL (kg/ha DM) & 1.77 & 0.59 & 3.20 & 0.72 & $* *$ \\
\hline Dehiscence seed loss DSL (\% DM) & 0.61 & 0.22 & 1.34 & 0.91 & * \\
\hline Harvesting seed LossHSL ( $\%$ DM) & 0.13 & 0.06 & 0.37 & 0.29 & * \\
\hline
\end{tabular}

There are many publications on the effect of mineral fertilization on the yield of fibrous hemp varieties [22,23]. In one of them, it was established that in the case of the CRS-1 and Anka cultivars, for increasing doses of N, P and K fertilization (0, 50, 100, 150 and $200 \mathrm{~kg}$ of $\mathrm{N}$ or $\mathrm{K}$ per 1 ha and $0,25,50,75$, and $100 \mathrm{~kg}$ of $\mathrm{P}$ per $1 \mathrm{ha}$ ) biomass yields and seeds increased from 1674 to $4209 \mathrm{~kg} / \mathrm{ha}$ and from 519 to $1340 \mathrm{~kg} / \mathrm{ha}$, respectively, with the use of $200 \mathrm{~kg} \mathrm{~N} /$ ha compared to the control. While hemp responded to nitrogen fertilization up to $200 \mathrm{~kg} / \mathrm{ha}$, the response to phosphorus and potassium fertilization was insignificant [24].

In another research, the response of two hemp varieties to increases in nitrogen, phosphorus, and sulfur fertilization at various locations in the Canadian province of Saskatchewan in 2006-2008 was also analyzed. The researchers found that increasing the nitrogen dose was significantly correlated with the yield of biomass and seeds. The maximum yield was achieved for a dose of approximately $150 \mathrm{~kg} \mathrm{~N} / \mathrm{ha}$. The Crag variety gave a higher yield of biomass than the Finola variety at all levels of nitrogen fertilization. However, increasing doses of this resulted in a greater percentage of seed yield increase in Finola cultivar. Consequently, the maximum seed yield was $27 \%$ higher for Finola than for the other variety. However, to achieve this maximum yield per unit of cultivation area for Finola, it was necessary to provide $198 \mathrm{~kg} \mathrm{~N} /$ ha of fertilizer compared to $175 \mathrm{~kg} \mathrm{~N} / \mathrm{ha}$ for the Crag cultivar. In addition, there was little or no response to phosphorus fertilization, on soils with adequate phosphorus availability, or to sulfur fertilizer on sulfur-deficient soils. These results indicate that the dose of nitrogen fertilizer and the characteristics of individual varieties are important factors that should be taken into account in the industrial production of hemp [25].

All analyzed scientific publications about hemp indicated a good response of this species to nitrogen fertilization, which was also confirmed by the results described in Table 3. for the Białobrzeskie variety. This cultivar has been described in many publications, which generally shows that the obtained results described in this article are higher in terms of plant height and seed yield [26,27]. A higher than average seed yield at a similar plant height results from the positive impact of the used harvesting technology (innovative prototype) on the seed yield of the Bialobrzeskie variety.

Focusing on seed loss, MS showed significantly higher values than FS, both regarding seed loss per natural dehiscence and seed loss directly related to harvesting operation. Such results were somehow expected, considering that several studies highlighted the significant influence of slope on the performance of agriculture machinery [28,29]. In this specific case, the difference in HSL can be related to the fact that MS hemp plants were shorter than in FS. This probably implies a more frequent impact of the cutting bar on the panicle leading to higher seed loss.

On the other hand, obtained values of seed loss, both in FS and MS, were very low, and this represents a very important finding of the present study. The performance of the prototype regarding this crucial parameter confirmed indeed that this machinery can work with a negligible value of seed loss also in conditions of moderate slope. 
The evaluated prototype seems to be a very valid solution mostly if compared to the few alternative machineries which have been scientifically evaluated till now. For instance, a recent study evaluated hemp seed harvesting via conventional combine harvester reporting a value of seed loss ranging between 46 and $26 \%$ of the harvestable yield [30].

\subsection{Working Performance and Harvesting Cost}

Results of the assessment of the working performance of the prototype are given in Table 5. The working speed of the prototype resulted significantly higher in FS than in MS, thus implying also a higher TFC in this condition. On the other hand, EFC and, interestingly, fuel consumption did not differ in a significant way between the two treatments. The reported working performance is in line with a typical mower of similar working width [31]. This aspect is of particular importance; indeed, the prototype was developed starting from a mower, and therefore, the fact that the working performance does not differ from one of the base machinery highlights that the modifications made to develop the prototype do not imply negative consequences on the performance of the harvesting system.

Table 5. Results of working performance analysis. "***” indicates statistically significant difference at $p<0.01$

\begin{tabular}{cccccc}
\hline & \multicolumn{2}{c}{ Flat Slope } & \multicolumn{2}{c}{ Moderate Slope } & \\
\hline Parameter & Avg. & St.Dev. & Avg. & St.Dev. & Significance Level \\
\hline Working speed $(\mathrm{km} / \mathrm{h})$ & 6.04 & 0.10 & 5.79 & 0.06 & $* *$ \\
$\quad \begin{array}{l}\text { Theoretical field } \\
\text { capacity TFC }(\text { ha } / \mathrm{h})\end{array}$ & 1.51 & 0.03 & 1.45 & 0.02 & $* *$ \\
Effective field capacity & 1.41 & 0.17 & 1.35 & 0.17 & n.s. \\
$\quad$ EFC (ha/h) & 34.81 & 4.01 & 34.21 & 4.46 & n.s. \\
Fuel consumption $(\mathrm{l} / \mathrm{h})$ & & &
\end{tabular}

In both treatments the field efficiency (ratio between EFC and TFC) reached a very high value of $93 \%$, highlighting the high maneuverability of the system prototype + tractor, which allowed for reduced turning times. Moreover, it is important to highlight also that proper delay time (such as stops related to clogging) did not occur if not sporadically. There are a few documented trials of working performance evaluation dealing with hemp seed harvesting, for instance, a combine harvester equipped with a modified header to collect simultaneously both seeds and stems showed an EFC of 2 ha/h [32]. The EFC obtained with the investigated prototype is therefore in line also with the results of machinery which is much bigger and expensive, even if considered for multipurpose harvesting. Higher productivity was reported for an innovative system developed in Germany to harvest simultaneously seeds and stems and based on a Claas Xerion 400 . This system reached an $\mathrm{EFC}$ of $2.9 \mathrm{ha} / \mathrm{h}$ thanks to the high working width, i.e., $6 \mathrm{~m} \mathrm{[33]} \mathrm{but} \mathrm{it} \mathrm{is} \mathrm{worth} \mathrm{highlighting}$ that also this machinery is designed for large-scale hemp cultivation to provide seeds and biomass for industry and not for certified seed production. Therefore, the tested prototype showed satisfactory results in terms also of working performance, considering that the reached value of almost 1.5 ha in both FS and MS is suitable to allow for efficient harvesting of hemp for certified seed sowing, considering the usually limited surface of these kinds of fields, as explained in the introduction of this manuscript.

Results of harvesting cost are instead reported in Figure 3. As it is possible to notice costs per surface unit are very similar between FS and MS (114.17 EUR/ha and 118.77 EUR/ha, respectively) while instead there is a difference of about $30 \mathrm{EUR} / \mathrm{Mg}$ (74.09 EUR/Mg for FS and 106.83 EUR/Mg for MS) between FS and MS, related to the lower average seed yield found in MS. 




Figure 3. Harvesting cost for FS and MS in terms of cost per surface unit and cost of biomass unit.

Interestingly, harvesting costs shown from the prototype resulted lower than what was reported for different machineries to harvest, also, hemp seeds. A range between 140.00 and $150.00 \mathrm{EUR} / \mathrm{ha}$ is indeed reported for harvesting systems based on modified combine harvesters [33], while lower costs of about $90.00 \mathrm{EUR} / \mathrm{ha}$ are reported for the stripper harvester Claas Xerion 400.

Therefore, also the economic evaluation of the investigated harvesting system showed satisfactory results; moreover, the values found for moderate slope working conditions are however sustainable, confirming the suitability of the investigated prototype to work also in conditions of slight marginality.

\section{Conclusions}

The mechanical harvesting of hemp seeds is still not properly developed yet., particularly in the case of some slopes. In the current study, a scientific evaluation was carried out regarding the performance of an innovative prototype for the harvesting of hemp seeds, focusing on the evaluation of seed loss, working productivity, and harvesting costs in two different conditions of a slope, i.e., flat slope (FS) and moderate slope (MS).

The obtained results highlighted a significant influence of terrain slope on seed loss, which resulted in significantly higher MS. However, the value of seed loss was practically negligible in both treatments highlighting the high efficiency of the prototype which showed much higher performance than usual combine-harvesters-based systems.

Furthermore, the evaluation of working productivity and cost are consistent with literature highlighting the advantage of using less expensive equipment for achieving good results. The limited harvesting cost associated with the prototype may encourage farmers to include hemp in rotation with the already cultivated crops to increase income and biodiversity in their farms.

Future studies should be carried out to confirm these preliminary results and, mostly, to test the prototype's performance also in conditions of even steeper slope.

Author Contributions: Conceptualization, P.B., F.L. and W.S.; methodology, P.B., F.L. and W.S.; formal analysis, P.B., F.L. and W.S.; writing-original draft preparation, P.B., F.L. and W.S.; J.F. and K.W.; writing-review and editing, P.B., F.L., W.S. and L.P.; supervision, P.B. and L.P.; funding acquisition, P.B. and L.P. All authors have read and agreed to the published version of the manuscript.

Funding: This research was funded by Horizon 2020 project Magic (grant number 727698).

Informed Consent Statement: Not applicable.

Conflicts of Interest: The authors declare no conflict of interest. 


\section{References}

1. European Commission Hemp Cultivation in Europe. Available online: https:/ / ec.europa.eu/info/food-farming-fisheries/plantsand-plant-products/plant-products/hemp_en (accessed on 22 October 2021).

2. Tsaliki, E.; Kalivas, A.; Jankauskiene, Z.; Irakli, M.; Cook, C.; Grigoriadis, I.; Panoras, I.; Vasilakoglou, I.; Dhima, K. Fibre and Seed Productivity of Industrial Hemp (Cannabis sativa L.) Varieties under Mediterranean Conditions. Agronomy 2021, $11,171$. [CrossRef]

3. Rehman, M.; Fahad, S.; Du, G.; Cheng, X.; Yang, Y.; Tang, K.; Liu, L.; Liu, F.-H.; Deng, G. Evaluation of hemp (Cannabis sativa L.) as an industrial crop: A review. Environ. Sci. Pollut. Res. 2021, 28, 52832-52843. [CrossRef]

4. Adesina, I.; Bhowmik, A.; Sharma, H.; Shahbazi, A. A Review on the Current State of Knowledge of Growing Conditions, Agronomic Soil Health Practices and Utilities of Hemp in the United States. Agriculture 2020, 10, 129. [CrossRef]

5. Ivanovs, S.; Rucins, A. Cutting of the biological mass of industrial hemp. J. Res. Appl. Agric. Eng. 2014, 59, 87-90.

6. EUROSTAT Data on Hemp Cultivation. Available online: http://appsso.eurostat.ec.europa.eu/nui/show.do?query= BOOKMARK_DS-905455_QID_-746CC6B4_UID_-3F171EB0\&layout=GEO,L,X,0;CROPS,B, Y,0;TIME,C,Z,0;STRUCPRO,L,Z,1; INDICATORS,C,Z,2;\&zSelection=DS-905455TIME,2009;DS-90 (accessed on 25 October 2021).

7. Sausserde, R.; Adamovics, A.; Ivanovs, S.; Bulgakov, V. Investigations into growing and harvesting hemp. J. Res. Appl. Agric. Eng. 2013, 58, 150-154.

8. Pari, L.; Baraniecki, P.; Kaniewski, R.; Scarfone, A. Harvesting strategies of bast fiber crops in Europe and in China. Ind. Crop. Prod. 2015, 68, 90-96. [CrossRef]

9. Sacristán, D.; Cifre, J.; Llompart, M.; Jaume, J.; Gulias, J. Lignocellulosic Biomass Production and Persistence of Perennial Grass Species Grown in Mediterranean Marginal Lands. Agronomy 2021, 11, 2060. [CrossRef]

10. Von Cossel, M.; Lewandowski, I.; Elbersen, B.; Staritsky, I.; Van Eupen, M.; Iqbal, Y.; Mantel, S.; Scordia, D.; Testa, G.; Cosentino, S.L.; et al. Marginal Agricultural Land Low-Input Systems for Biomass Production. Energies 2019, 12, 3123. [CrossRef]

11. Elbersen, B.; van Eupen, M.; Verzandvoort, S.; Boogaard, H.; Mucher, S.; Cicarreli, T.; Elbersen, W.; Mantel, S.; Bai, Z.; Iqbal, Y.; et al. Deliverable 2.6 of Horizon 2020 Project Magic. Methodological approaches to identify and map marginal land suitable for industrial crops in Europe. 2018. Available online: https:/ / zenodo.org/record/3539311 (accessed on 25 October 2021).

12. Pari, L.; Latterini, F.; Stefanoni, W. Herbaceous Oil Crops, a Review on Mechanical Harvesting State of the Art. Agriculture 2020, 10, 309. [CrossRef]

13. Reith, S.; Frisch, J.; Winkler, B. Revision of the working time classification to optimize work processes in modern agriculture. Chem. Eng. Trans. 2017, 58, 121-126.

14. Assirelli, A.; Pignedoli, S. Costo di esercizio delle macchine agricole. Cent. Ric. Prod. Anim. 2005, 5, 1-10.

15. Magagnotti, N.; Spinelli, R.; Kärhä, K.; Mederski, P.S. Multi-tree cut-to-length harvesting of short-rotation poplar plantations. Eur. J. For. Res. 2020, 140, 345-354. [CrossRef]

16. American Society of Agricultural Engineers. ASAE standard D497.4. Agriculture Machinery Management Data; American Society of Agricultural and Biological Engineers: St. Joseph, MI, USA, 2003; pp. 373-380.

17. Callaway, J.C. Hempseed as a nutritional resource: An overview. Euphytica 2004, 140, 65-72. [CrossRef]

18. Poisa, L.; Adamovics, A. Hemp (Cannabis sativa L.) as an Environmentally Friendly Energyplant. Sci. J. Riga Tech. Univ. Environ. Clim. Technol. 2010, 5, 80-85. [CrossRef]

19. Łochyńska, M.; Frankowski, J. The Effects of Silkworm Excrement Organic Fertilizer on the Hemp Yield. J. Nat. Fibers 2021, 1-11. [CrossRef]

20. Papastylianou, P.; Kakabouki, I.; Travlos, I. Effect of Nitrogen Fertilization on Growth and Yield of Industrial Hemp (Cannabis sativa L.). Not. Bot. Horti Agrobot. Cluj-Napoca 2017, 46, 197-201. [CrossRef]

21. Tang, K.; Struik, P.; Yin, X.; Calzolari, D.; Musio, S.; Thouminot, C.; Bjelková, M.; Stramkale, V.; Magagnini, G.; Amaducci, S. A comprehensive study of planting density and nitrogen fertilization effect on dual-purpose hemp (Cannabis sativa L.) cultivation. Ind. Crop. Prod. 2017, 107, 427-438. [CrossRef]

22. Finnan, J.; Burke, B. Nitrogen fertilization to optimize the greenhouse gas balance of hemp crops grown for biomass. GCB Bioenergy 2013, 5, 701-712. [CrossRef]

23. Van der Werf, H.; van Geel, W.; van Gils, L.; Haverkort, A. Nitrogen fertilization and row width affect self-thinning and productivity of fibre hemp (Cannabis sativa L.). Field Crop. Res. 1995, 42, 27-37. [CrossRef]

24. Aubin, M.; Seguin, P.; Vanasse, A.; Tremblay, G.F.; Mustafa, A.F.; Charron, J. Industrial Hemp Response to Nitrogen, Phosphorus, and Potassium Fertilization. Crop Forage Turfgrass Manag. 2015, 1, 1-10. [CrossRef]

25. Vera, C.L.; Malhi, S.S.; Phelps, S.M.; May, W.E.; Johnson, E.N. N, P, and S fertilization effects on industrial hemp in Saskatchewan. Can. J. Plant Sci. 2010, 90, 179-184. [CrossRef]

26. Wielgusz, K.; Praczyk, M.; Irzykowska, L.; Świerk, D. Fertilization and soil pH affect seed and biomass yield, plant morphology, and cadmium uptake in hemp (Cannabis sativa L.). Ind. Crop. Prod. 2021, 175, 114245. [CrossRef]

27. Grabowska, L.; Koziara, W. The Effect of Nitrogen Dose, Sowing Density and Time of Harvest on Development and Yields of Hemp Cultivar Bialobrzeskie. J. Nat. Fibers 2006, 2, 1-17. [CrossRef]

28. Latterini, F.; Stefanoni, W.; Suardi, A.; Alfano, V.; Bergonzoli, S.; Palmieri, N.; Pari, L. A GIS Approach to Locate a Small Size Biomass Plant Powered by Olive Pruning and to Estimate Supply Chain Costs. Energies 2020, 13, 3385. [CrossRef] 
29. Suardi, A.; Latterini, F.; Alfano, V.; Palmieri, N.; Bergonzoli, S.; Karampinis, E.; Kougioumtzis, M.A.; Grammelis, P.; Pari, L. Machine Performance and Hog Fuel Quality Evaluation in Olive Tree Pruning Harvesting Conducted Using a Towed Shredder on Flat and Hilly Fields. Energies 2020, 13, 1713. [CrossRef]

30. Faugno, S.; Sannino, M.; Crimaldi, M.; Caracciolo, G.; Assirelli, A. Hemp seed mechanical harvesting efficiency analysis. In Proceedings of the 26th European Biomass Conference and Exhibition, Copenaghen, Denmark, 14-17 May 2018 ; pp. $374-377$.

31. Bianchi, P.G.; Castelli, P.G.; Centolani, G.; Cugudda, L.; Di Vittorio, G.; Ferrarotti, M.; Guadagni, A.; Lechi, G.M.; Milani, G.; Morini, M.; et al. Agriculture Handbook (In Italian), 2nd ed.; Hoepli, U., Ed.; Hoepli: Milano, Italy, 2015.

32. Pari, L.; Alfano, V.; Scarfone, A. An innovative harvesting system for multipurpose hemp. In Proceedings of the 24th International European Biomass Conference on Setting the Course for a Biobased Economy, Florence, Italy, 6-9 June 2016; pp. 356-358.

33. Gusovius, H.-J.; Hoffmann, T.; Budde, J.; Lühr, C. Still special? Harvesting procedures for industrial hemp. Landtechnik 2016, 71, 14-24. [CrossRef] 